\title{
Not enough parking, you say? A study of garage use and parking supply for single-family homes in Sacramento and implications for ADUs
}

\author{
Jamey M. B. Volker (corresponding author) \\ Institute of Transportation Studies \\ University of California, Davis \\ jvolker@ucdavis.edu
}

\author{
Calvin G. Thigpen \\ thigpen.calvin.g@gmail.com
}

\begin{abstract}
Accessory dwelling units (ADUs) are increasingly touted as part of the solution to the intransigent housing shortages facing many metropolitan areas across the United States. But numerous barriers to ADU development persist, including opposition by neighboring households. One persistent question is whether ADU residents would overwhelm on-street parking in the predominately single-family neighborhoods where ADUs are typically built. That question is difficult to answer because there is a surprising dearth of research on the effective parking supply in single-family neighborhoods. We use a survey of homeowners in Sacramento, California, to investigate the supply and sufficiency of residential parking for single-family homes, including how households actually use their garages, and help answer the ADU parking conundrum. After estimating and accounting for actual garage use, we find that more than $75 \%$ of households have enough off-street parking available to park all their vehicles. When we combine off-street and onstreet parking supplies, we find that households have an average of 1.6 more parking spaces available to them than they have vehicles. That parking surplus is more than enough to accommodate the average ADU tenant and their vehicle, belying claims that ADUs will overwhelm existing parking supplies in single-family neighborhoods.
\end{abstract}

\section{Article history:}

Received: December 18, 2020

Received in revised form: August 14, 2021

Accepted: December 9, 2021

Available online: February 28,

2022

\section{Introduction}

Accessory dwelling units—or "ADUs" — are smaller, self-contained housing units that share the same lot as a larger primary dwelling, usually a single-family detached house (Chapple et al., 2017). ${ }^{1}$ ADUs can be constructed anew (either as standalone structures or extensions of the primary dwelling) or converted from existing structures on the lot (like garages) or an interior portion of the larger dwelling. ADUs are often touted as a time- and cost-effective way to increase housing supply, particularly in areas like California with major housing supply shortages (Casey, 2020; Woetzel et al., 2016). One study even estimated that ADU-like developments could provide half of California's new housing capacity in

Copyright 2022 Jamey M. B. Volker \& Calvin G. Thigpen

http://dx.doi.org/10.5198/jtlu.2022.1947

ISSN: 1938-7849 | Licensed under the Creative Commons Attribution - Noncommercial License 4.0

The Journal of Transport and Land Use is the official journal of the World Society for Transport and Land Use (WSTLUR) and is published and sponsored by the University of Minnesota Center for Transportation Studies. This paper is also published with additional sponsorship from WSTLUR.

${ }^{1}$ It was not until 2019 that California state law was amended to explicitly allow ADUs on lots with multifamily dwellings (California Assembly Bill 881, 2019-2020). 
the coming decades (Woetzel et al., 2016). But spurring ADU development has proved difficult.

In addition to difficulties obtaining financing and other obstacles, homeowners across the United States have faced significant regulatory barriers to permitting ADUs. One of the most significant barriers has been onerous parking mandates, like requiring provision of additional off-street parking for the ADU or requiring the replacement of covered parking spaces that are eliminated to make space for the ADU (Anacker \& Niedt, 2019; Brown et al., 2017; Chapple et al., 2012; Cho, 2016; Morales, 2019; Pfeiffer, 2019; Wegmann \& Chapple, 2012). In an effort to reduce these parking-related burdens and other regulatory barriers, California recently changed state law to make it easier than ever before to permit ADUs (California Government Code Section 65852.2, n.d.; Volker, 2020). Some local governments have loosened the regulations even further. In Sacramento- the geographical focus of this study - the city does not require off-street parking spaces for ADUs under any circumstance (City of Sacramento, 2021a).

Perversely, however, reducing off-street parking requirements can exacerbate neighborhood opposition to ADUs. Insufficient on-street parking is already one of the concerns most commonly cited by neighboring households in opposing proposed ADUs (Anacker \& Niedt, 2019; Brown et al., 2017; Chapple et al., 2012; Wegmann \& Chapple, 2012). And ADUs are more likely to increase demand for on-street parking if there is no requirement that homeowners add off-street parking to accommodate the ADU-generated vehicles or replace any off-street parking spaces eliminated to make room for the ADU. Indeed, the results from a recent survey of California's local governments indicate that " $[\mathrm{w}]$ ith the new state ADU legislation, ... the public is the most concerned about parking" (Chapple et al., 2020). That begs the question - is the total effective parking supply of the average single-family detached home sufficient to accommodate the vehicles generated by both the household in the primary dwelling and the household in a potential ADU?

This seemingly simple question of supply and demand is not easily answered with existing studies. One might expect there to be ample evidence on parking supply and demand in single-family neighborhoods, given the prevalence of minimum residential parking standards across the US. Despite their importance, however, those standards are notoriously based on thin to non-existent evidence (Guo et al., 2012; Willson, 2000). We likewise found a dearth of research on the effective parking supply in single-family neighborhoods, let alone research that compares supply to actual demand. This study helps fill those knowledge gaps and answer the ADU parking conundrum using a survey of single-family detached homeowners in Sacramento, California $(n=396)$.

In the rest of the paper, we review the literature on parking supply in single-family neighborhoods, survey the research on garage use (in order to ascertain actual availability for parking), and describe how we evaluated garage use and estimated effective parking supply and surplus. We then compare our findings to previous studies and discuss the implications for ADU development. Considering total effective parking supply (off-street and on-street combined), we find that the average household has 1.6 to 2.0 more parking spaces available to them than they have vehicles, suggesting a sufficient parking supply to accommodate ADUs in single-family home neighborhoods.

\section{$2 \quad$ Literature review}

The total or "nominal" parking supply for a single-family detached home equals (1) the number of on-street parking spaces generally available to that household plus (2) the number of off-street parking spaces nominally available to the household for parking a vehicle. The "effective" parking supply for a single-family detached home equals the total parking supply minus the number of off-street spaces actually used for other purposes. The effective parking "surplus" equals the effective parking supply minus 
the number of vehicles parked on site by the occupants of the parcel (be it homeowners, ADU renters, or others). We first review the studies that attempt to look at the big picture-total parking supply, effective parking supply, and/or effective parking surplus. We then review the related but distinct subset of studies that focus on the actual use of off-street parking (primarily garages).

\subsection{Parking supply and surplus for single-family detached homes}

Single-family detached homes often have both private off-street parking (like garages, carports, driveways, or even yards) and access to on-street parking (Guo, 2013). Despite frequent access to on-street parking, local zoning laws in many US cities require that single-family homes contain off-street parking for the purpose of car storage (Guo et al., 2012). Data for both on- and off-street parking are needed to estimate the total effective parking supply and surplus for a given household or in a given neighborhood. But this data is often lacking or unavailable (Guo, 2013; Guo \& Schloeter, 2013; Taylor, 2020; Thigpen $\&$ Volker, 2017). Consequently, the literature contains scant research on parking supplies and surpluses in single-family neighborhoods, as previous reviews confirm (Anirudh et al., 2021; Guo, 2013; Scheiner et al., 2020; Taylor, 2020; Thigpen \& Volker, 2017).

Guo et al. (2012) and Guo (2013) come the closest we have seen to estimating a total parking supply for single-family homes. Guo et al. ( 2012) investigated on-street parking requirements in residential neighborhoods in the US. As part of their analysis, they estimated that the average single-family home in the US has access to 8-10 parking spaces, including 2.6 garage spaces, 4-5 on-street spaces, and 1-3 driveway spaces. They calculated the number of garage spaces using data on garage size (i.e., theoretical garage capacity, not actual availability for auto parking after accounting for other garage uses). They estimated the number of on-street spaces using an average lot size $(0.34$ acres $)$ for single-family homes built in US metro areas between 1970 and 2010, an assumed frontage-depth ratio of 2:3 for those lots, and an average length of 20 feet for on-street parking spaces (Guo et al., 2012). They estimated an average of 110 feet of street line per home, which translates to four or five parking spaces, depending on the curb cut length. Guo (2013) replicated the same calculus in a subsequent article analyzing the effect of on-street parking on car ownership in the New York City region.

Thigpen and Volker (2017), Schlossberg and Amos (2015), and Roth (2016) calculated on-street parking supply and vacancy rates for predominately single-family neighborhoods in Davis, California, Eugene, Oregon, and Bellevue, Washington, respectively. They all found that on-street parking was oversupplied, with vacancy rates between $71 \%$ and $89 \%$ at times of peak occupancy. Schlossberg and Amos (2015) also tallied driveway parking spaces in the same Eugene neighborhoods. But none of the three studies estimated total parking supplies or surplus for the households in the subject neighborhoods, let alone extrapolated the results beyond their specific samples.

As part of a study on the market for ADUs, Wegmann and Chapple (2012) calculated the average number of available off-street spaces for a (nearly) random sample of single-family homeowners near Bay Area Rapid Transit stations in five cities on the east side of the San Francisco Bay Area. They found that households with at least one ADU reported an average of 1.86 available off-street parking spaces (in garages, driveways, or elsewhere off street), while households without ADUs reported an average of 1.67 available off-street spaces (an insignificant difference statistically). They also calculated the average number of "overspill" vehicles - the difference between the number of cars generated by the property (including any ADUs) and the number of available off-street parking spaces. They found that properties with ADUs had an average overspill of 1.09 vehicles, while households without ADUs had an average overspill of 0.35 vehicles. However, they did not estimate the number of available on-street spaces per home or, consequently, total effective parking surplus.

Taylor (2020) presented more comprehensive household survey data than previous studies about 
residential parking availability, use, and sufficiency for a sample of households in Melbourne, Australia, $59 \%$ of whom lived in a single-family detached home. Taylor found that $74 \%$ of respondents had "sufficient" off-street parking, i.e., they had at least the same number of available off-street spaces as vehicles. But the study did not present the total effective parking supply or surplus for those households.

Overall, the available literature indicates that parking is generally oversupplied in single-family neighborhoods. But estimates of the total effective parking supply and surplus for single-family detached homes are sorely lacking, particularly estimates using actual—or "effective"—off-street parking space availability (adjusting the nominal off-street capacity based on how households actually use those spaces). Our study helps fill this gap.

\section{$2.2 \quad$ Use of off-street parking}

Estimating effective parking supply and surplus requires knowing how ostensibly available off-street parking spaces are actually used, particularly garage parking (since it is enclosed and therefore more likely to be used for purposes other than parking). Most studies of parking supply in single-family neighborhoods do not address this in detail, as discussed above. The few studies that do investigate off-street parking use focus on garages.

Many of the contemporary studies of personal garage use in the US focus on the Los Angeles region. In 1987, Los Angeles Times reporters undertook a systematic study of garage use and found that $3.2 \%$ were inhabited (Chavez \& Quinn, 1987). A subsequent study of 32 "middle-class" households reported that $75 \%$ of garages were used exclusively for storage of household belongings (Arnold et al., 2012). The authors further estimated that roughly $90 \%$ of garage space in middle-class Los Angeles neighborhoods is used for storage rather than parking. A peer-reviewed journal article using a subset of the same data provided additional detail (Arnold \& Lang, 2007). According to the authors, only one household out of twenty-four did not use some or all of their garage for storage. The study's methodology, based on archaeological approaches, notes that garages are overwhelming used by this segment of the population as an overflow area for material possessions and food. More informally, a City of Compton official estimated that roughly a third of the city's garages were used for housing people rather than cars (Garrison, 2009). And an informal estimate by Wegmann (2015) suggested that a majority of garages in the Southeast Los Angeles area had been converted for residential purposes.

Beyond the Los Angeles region, we identified seven other studies that attempted to estimate garage uses. In a survey of planning professionals in nearly 100 major US cities, over a quarter identified storage as a "very common" use for garages and another two-thirds said it was "common" (Guo \& Schloeter, 2013). A study of garages in the Mission District neighborhood of San Francisco found that $49 \%$ of the 97 garages observed during field observations were not used for car parking (Brown, 2007). In a 1998 New York Metropolitan Transportation Council survey, only 13\% of households with garages parked their car in the garage - the remainder parked cars in their driveway and on the street (Guo, 2013). Jenks and Noble (1996) surveyed homeowners with one-car garages in a suburb outside of Reading, England and found that 38\% of garages were not used to store vehicles (as cited in Guo \& Schloeter, 2013, 460). A review of studies conducted in the United Kingdom found that between 36\% and 45\% of garages were used for car parking (United Kingdom Department for Transport, 2007). More recently, an opinion panel of UK drivers similarly found that $53 \%$ of drivers with garages never use them for car parking and only $40 \%$ park in their garage on a regular basis (RAC Media Center, 2021). In a survey of Melbourne, Australia residents, Taylor (2020) found that of the respondents living in single-family detached homes, $41 \%$ used their off-street parking only for car parking, $35 \%$ for car parking and other uses (e.g., storage, living areas), and $18 \%$ for only non-car parking purposes. 
Table 1. Estimates of garage uses in the literature

\begin{tabular}{|c|c|c|c|c|c|}
\hline Study & Setting & Methods & Living/ADU & Storage & Parking \\
\hline $\begin{array}{r}\text { Arnold et al. } \\
\text { (2012) }\end{array}$ & Los Angeles area & $\begin{array}{l}\text { Ethnographic } \\
\text { study of } 32 \text { dual- } \\
\text { earner households }\end{array}$ & - & $75 \%$ & - \\
\hline Brown (2007) & San Francisco & Field observation & - & - & $51 \%$ \\
\hline $\begin{array}{r}\text { Chavez \& Quinn } \\
\text { (1987) }\end{array}$ & $\begin{array}{r}\text { Los Angeles } \\
\text { County } \\
\end{array}$ & $\begin{array}{r}\text { Systematic sam- } \\
\text { pling } \\
\end{array}$ & $3.2 \%$ & - & - \\
\hline $\begin{array}{l}\text { United Kingdom } \\
\text { Department for } \\
\text { Transport (2007) }\end{array}$ & England & $\begin{array}{r}\text { Review of the } \\
\text { literature }\end{array}$ & - & - & $36-45 \%$ \\
\hline Garrison (2009) & $\begin{array}{l}\text { Compton, } \\
\text { California }\end{array}$ & Informal estimate & $33 \%$ & - & - \\
\hline Guo et al. (2012) & United States & $\begin{array}{r}\text { Expert opinion } \\
\text { survey }\end{array}$ & - & $\begin{array}{r}27 \% \text { : "very } \\
\text { common;" 63\%: } \\
\text { "common" }\end{array}$ & - \\
\hline Guo (2013) & New York City & $\begin{array}{r}\text { Survey of } \\
\text { households }\end{array}$ & - & - & $13 \%^{a}$ \\
\hline $\begin{array}{l}\text { Jenks \& Noble } \\
(1996) \text {, as cited in } \\
\text { Guo and Schlo- } \\
\text { eter }(2013,460)\end{array}$ & $\begin{array}{r}\text { United Kingdom } \\
\text { suburb }\end{array}$ & $\begin{array}{l}\text { Survey of one-car } \\
\text { garage households }\end{array}$ & - & - & $62 \%$ \\
\hline RAC (2021) & United Kingdom & $\begin{array}{r}\text { Opinion panel } \\
\text { survey }\end{array}$ & & & $\begin{array}{r}40 \% \text { regularly; } \\
8 \% \text { occasionally }\end{array}$ \\
\hline Taylor (2020) & $\begin{array}{r}\text { Melbourne, } \\
\text { Australia }\end{array}$ & $\begin{array}{r}\text { Convenience } \\
\text { sampling }\end{array}$ & - & $18 \%$ & $\begin{array}{r}41 \% \text { only, } 35 \% \\
\text { with storage or } \\
\text { other use }\end{array}$ \\
\hline Wegmann (2015) & $\begin{array}{r}\text { Southeast } \\
\text { Los Angeles }\end{array}$ & Informal estimate & majority & - & - \\
\hline
\end{tabular}

a Statistic refers to houses with garages

Other studies have also weighed in on the topic of garage use or, more expansively, off-street parking use. For example, a study of residential parking patterns in a dense, mixed-use neighborhood of Dortmund, Germany found that roughly a third (37\%) of households with private off-street parking always used that space to store a car, while ten percent never used it for car parking (Scheiner et al., 2020). Our study adds to this small, yet slowly growing, body of research on off-street parking use.

\section{$3 \quad$ Methods}

\subsection{Setting}

We conducted this study in Sacramento-California's capital city and its sixth most populous, with over 508,000 residents (US Census Bureau, 2018a). California is a prime location to study residential parking supply and its implications for ADU development. The state is mired in a major housing supply and affordability crisis that has been exacerbated by decades of planning and building for automobility, including capacious street width standards and off-street parking requirements (Guo et al., 2012; Volker et al., 2019). The state government has recently embraced ADUs as an integral part of solving the housing crisis and changed state law to make it easier than ever before to permit ADUs (California Govern- 
ment Code Section 65852.2, n.d.; Volker, 2020). Yet concerns about inadequate parking in residential neighborhoods_especially single-family neighborhoods_-could hinder ADU construction.

Sacramento is a natural setting for this study within California because single-family detached homes dominate the city's housing stock to a greater extent than most of the state's other urban areas. Over $60.4 \%$ of Sacramento's housing units are single-family detached houses (US Census Bureau, 2018b). In total, Sacramento has over 118,000 single-family detached homes (US Census Bureau, 2018b).

Sacramento is also a prime location for studying the implications of residential parking supply for housing development, and particularly ADUs, because it is one of California's fastest growing cities. Sacramento added more people between 2018 and 2019 than all but one (Chico) of California's 482 cities (California Department of Finance, 2019). And it grew at a faster rate (1.49\%) than any of the other top-10 most populous cities in the state (California Department of Finance, 2019). Yet the city actually lost $2.4 \%$ of its housing units between 2017 and 2018 (US Census Bureau, 2018a, 2017). Meanwhile, Sacramento's vacancy rate dropped from 6.6\% in 2010 to 4.2\% in 2018 (US Census Bureau, 2018b, 2010).

The conditions would appear particularly ripe for ADU development in Sacramento because up to $47 \%$ of single-family detached homeowners in Sacramento could be open to building an ADU according to a recent study that used the same survey data we use in this study (Volker \& Handy, in press). Yet the numbers of ADU permits applied for and issued in Sacramento remain relatively low compared to the jump in ADU permitting seen in other large cities following Californias relaxation of ADU restrictions starting in 2016. Sacramento received only 162 ADU permit applications in 2020 (City of Sacramento, 2021b), up from 83 in 2019. ${ }^{2}$

Parking-related impediments are certainly not the only reason why Sacramento has lagged behind other large California cities in ADU permitting. Indeed, Sacramento does not require off-street parking for ADUs (City of Sacramento, 2021a). Nor, per state law, does it require the replacement of covered off-street parking spaces eliminated to make room for an ADU (California Government Code Section 65852.2 , n.d.). But neighborhood opposition fueled by concerns about insufficient parking and traffic can be a formidable obstacle for homeowners who are considering adding an ADU. Another analysis of the same 2019 survey data that we use in this study found that the majority of Sacramento-area singlefamily homeowners who reported being open to adding an ADU ranked "opposition from neighbors" as at least a "minor obstacle" to creating an ADU (Volker, 2020). And parking and traffic issues appeared to be the most likely source of opposition. When asked whether they thought that a neighbor renting out an ADU would "have a negative impact on the neighborhood," $46 \%$ of all surveyed homeowners responded that it would result in "too many cars trying to park on my street."

\subsection{Gauging garage use and effective off-street parking supply}

To better understand garage use and effective off-street parking supply in single-family detached homes, we surveyed a sample of single-family detached homeowners in Sacramento in the summer of 2019 (July through August).

\subsubsection{Data collection and respondent snapshot}

We recruited participants for our online survey from three separate sources. Our first recruitment came from a set of double-opt-in panels maintained by the experience management company Qualtrics. Qualtrics administered the survey in late July and early August 2019 to 351 respondents who passed the screening question, finished the online survey, and did not provide any unintelligible or clearly

\footnotetext{
${ }^{2}$ Matt Hertel, Principal Planner, City of Sacramento, email message to author, April 15, 2020.
} 
unresponsive answers to the text response questions (to weed out unserious respondents). We obtained our second recruitment list through the 2018-2019 campus travel survey at the University of California, Davis; 143 respondents said they would be willing to let us contact them again for this study. We garnered the third recruitment list through two surveys about the JUMP bikeshare program in the Sacramento region; 440 respondents replied that they would be willing to take a future survey. We compared the recruitment lists from the campus travel survey and JUMP bike surveys and removed any duplicate email addresses. We emailed an invitation and link to take our ADU survey to all 583 unique recruits from the second and third recruitment lists in mid-August 2019. Over half (312) of the recruits both passed the screening question (owning their own home) and at least partially completed the online survey. None reported having previously taken our survey as part of a Qualtrics panel, but we could not independently verify this because the names and email addresses for the Qualtrics respondents were kept confidential. As an additional check for "ballot-box stuffing", we examined the socio-demographic responses and did not identify any duplicates, providing supportive evidence that responses came from unique respondents. In total, we garnered 663 unique respondents across the three recruitment pools.

To further improve data quality, we excised the 106 respondents who either did not answer the primary questions of interest or failed to answer at least five other questions. We then culled the remaining 557 complete cases by removing (1) all respondents who did not own a single-family detached home, and (2) all respondents who lived outside of the City of Sacramento. That yielded a final sample size of 396 single-family detached homeowners living in Sacramento.

Table 2 compares the housing stock and demographic characteristics of our sample to those of the population of interest-householders owning a single-family detached home in Sacramento. Our sample is younger, whiter, more educated, and has a greater percentage of people who have lived in the same home for less than 10 years than the homeowner population of Sacramento. The average household size and percentage of households with more than two vehicles are also slightly greater in our sample than in the city's overall population of homeowning householders.

Table 2. Characteristics of sampled homeowners compared to the population of Sacramento homeowners

\begin{tabular}{|c|c|c|}
\hline & $\begin{array}{c}\text { City of Sacramento } \\
\text { Homeowner Sample } \\
\end{array}$ & $\begin{array}{c}\text { City of Sacramento Home- } \\
\text { owner Population }^{\text {a }}\end{array}$ \\
\hline Sample size & 396 & - \\
\hline \multicolumn{3}{|l|}{ Housing Stock ${ }^{\mathbf{a}}$} \\
\hline Number of owner-occupied housing units & 396 & $89,678(+/-4,030)$ \\
\hline Number of owner-occupied single-family detached units & 396 & $79,816(+/-3,770)$ \\
\hline \multicolumn{3}{|l|}{ Demographics $^{\mathrm{a}}$} \\
\hline Median age or age bracket & $46(45-54)$ & $55-64$ \\
\hline Median income or income bracket & $\$ 75,000$ - \$99,999 & $\$ 82,959(+/-1,525)$ \\
\hline Share with bachelor's degree or higher & $63.1 \%$ & $45.4 \%(+/-1.0)$ \\
\hline Share non-Hispanic white & $60.4 \%$ & $48.9 \%(+/-0.9)$ \\
\hline Share with 10 or fewer years in current home ${ }^{b}$ & $49.5 \%$ & $33.6 \%$ \\
\hline Share with 3 or more vehicles & $24.8 \%$ & $24.0 \%$ \\
\hline Average household size & 2.87 & $2.76(+/-0.03)$ \\
\hline
\end{tabular}

Notes:

${ }^{\text {a }}$ Housing stock estimates for the City of Sacramento obtained from table S2504 from the American Community Survey's 2018 1-year estimates (US Census Bureau, 2018a). Demographic estimates obtained from tables S2502, S2503, B25010, and B25044 from the American Community Survey's 2018 5-year estimates (US Census Bureau, 2018b). Demographic estimates are for all owner-occupied housing units, the majority of which are single-family detached units.

${ }^{b}$ For the City of Sacramento homeowner population, this equals the share of homeowners who have moved into their current home in 2010 or later (8 or fewer years before the 2018 American Community Survey). 


\subsubsection{Survey weighting}

We weighted the sample to represent the population of single-family homeowners in Sacramento using two key variables likely to influence garage and off-street parking use: household size and number of cars available. In order to estimate the full cross-tabulation of these two characteristics, for the population of owner-occupied, single-family detached households in the City of Sacramento, we downloaded 2019 5-year American Community Survey Public Use Microdata Sample (PUMS) data from the Census for the Public Use Microdata Areas (PUMAs) that contain the City of Sacramento boundaries (US Census Bureau, 2003a, 2003b). By using PUMS data, we were able to estimate cell values for the contingency table of household size by vehicle availability and therefore use post-stratification cell weighting (Kalton \& Flores-Cervantes, 2003). PUMAs align closely, but not perfectly, with City of Sacramento boundaries. We tested the sensitivity of the contingency table's cell values to which PUMAs were included to represent our population and found minimal differences - the greatest difference between any two sets of PUMA combinations was two percentage points for one cell.

Because the cell sizes for households with 0 cars and 4 or more cars in our sample were very small, we collapsed those categories together with the adjacent vehicle availability categories, yielding 3 vehicle availability categories for weighting: 1 or less, 2 , and 3 or more cars. The weights range from a low of 0.51 to a high of 3.55 (Table 3 ).

Table 3. Survey weights for sample based on household size and cars available

\begin{tabular}{|c|c|c|c|c|c|}
\hline Household size & Cars available & Sample & Census & $\begin{array}{l}\text { Percentage point } \\
\text { difference } \\
\text { (Sample - Census) }\end{array}$ & Survey weight \\
\hline \multirow{3}{*}{1} & 1 or less & $7.1 \%$ & $6.1 \%$ & 0.9 & 0.86 \\
\hline & 2 & $1.8 \%$ & $1.5 \%$ & 0.3 & 0.86 \\
\hline & 3 or more & $0.8 \%$ & $0.4 \%$ & 0.3 & 0.67 \\
\hline \multirow{3}{*}{2} & 1 or less & $6.8 \%$ & $5.3 \%$ & 1.5 & 0.78 \\
\hline & 2 & $26.5 \%$ & $14.5 \%$ & 12.0 & 0.54 \\
\hline & 3 or more & $8.8 \%$ & $4.6 \%$ & 4.3 & 0.51 \\
\hline \multirow{3}{*}{3} & 1 or less & $2 \%$ & $2.5 \%$ & -0.5 & 1.25 \\
\hline & 2 & $11.9 \%$ & $8 \%$ & 3.8 & 0.68 \\
\hline & 3 or more & $5.3 \%$ & $6.6 \%$ & -1.3 & 1.24 \\
\hline \multirow{3}{*}{4} & 1 or less & $1.5 \%$ & $1.5 \%$ & 0.0 & 1.00 \\
\hline & 2 & $12.9 \%$ & $10.5 \%$ & 2.4 & 0.82 \\
\hline & 3 or more & $4.8 \%$ & $8.8 \%$ & -4.0 & 1.84 \\
\hline \multirow{3}{*}{5 or more } & 1 or less & $1.5 \%$ & $2.3 \%$ & -0.8 & 1.50 \\
\hline & 2 & $3.3 \%$ & $9.4 \%$ & -6.1 & 2.85 \\
\hline & 3 or more & $5.1 \%$ & $18 \%$ & -12.9 & 3.55 \\
\hline
\end{tabular}

\subsubsection{Survey questions and data analysis}

We used our weighted data to explore off-street parking supply and surplus, including garage use. Table 4 shows the relevant questions we asked respondents about garage availability, garage use, the availability of other off-street parking, and vehicle availability. 
Table 4. Survey questions used in garage use and off-street parking supply analyses

\begin{tabular}{|c|c|}
\hline Questions & Answer options \\
\hline \multirow{4}{*}{ Does your home have a garage? } & Yes, a 1-car garage \\
\hline & Yes, a 2-car garage \\
\hline & Yes, a 3+-car garage \\
\hline & No \\
\hline \multirow{6}{*}{ How do you use your garage? Please check all that apply. } & For automobile storage and repair \\
\hline & For other storage \\
\hline & $\begin{array}{r}\text { As an additional bedroom or independent living space for } \\
\text { my household }\end{array}$ \\
\hline & As an independent living space rented to others \\
\hline & $\begin{array}{r}\text { As an office, play room, laundry room, or other type of } \\
\text { additional room }\end{array}$ \\
\hline & Other. Please specify: \\
\hline $\begin{array}{r}\text { How many off-street automobile parking spaces does your } \\
\text { home have outside of a garage (e.g. spaces in an uncovered } \\
\text { driveway or covered carport)? }\end{array}$ & Numeric response \\
\hline $\begin{array}{r}\text { How many automobiles does your household own (or lease) } \\
\text { and park at home? }\end{array}$ & Numeric response \\
\hline
\end{tabular}

For our garage use analysis, we used the weighted responses to the "How do you use your garage?" question shown in Table 4 to estimate the population-level prevalence of different garage uses. We estimated the frequency of each individual garage use as well as the frequency of each unique combination of simultaneous garage uses (since respondents were allowed to select multiple concurrent uses). Where respondents selected "Other" as one of their garage uses, we asked them to specify the other use. Because all of the answers to the "other" category were elaborations or examples of the five closed-ended options, we were able to re-code all of the "other" answers as one or more of the closed-ended answers provided.

For our off-street parking supply and surplus analysis, we used the weighted responses to the Table 4 questions to estimate the average off-street parking supply and surplus (available spaces minus household vehicles) for single-family detached homeowners in Sacramento. We also estimated the populationlevel distribution of households across 10 levels of off-street parking sufficiency, ranging from a maximum surplus of six or more off-street parking spaces remaining to a maximum shortage of exceeding off-street parking availability by three or more spaces. These estimates required three inputs-number of vehicles parked at home per household, number of garage spaces available to each household, and number of non-garage off-street parking spaces available to each household.

To calculate the number of vehicles and non-garage off-street parking spaces available to each respondent household, we simply used their numeric responses to questions 3 and 4 in Table 4 . To estimate the number of "available" garage spaces, we used three scenarios based on respondents' answers to the first two questions in Table 4 -nominal garage vehicle capacity and actual garage use. The first scenario is a hypothetical "maximum supply" scenario, in which each household is assumed to have their full garage capacity available for vehicle parking-i.e., 0,1 , 2, or 3 spaces based on respondents' answers to question 1-regardless of how respondents actually use their garage (question 2).

The second and third scenarios provide rough upper and lower estimates for actual garage parking space availability, adjusting the nominal garage capacity based on how respondents report using their garages. The "actual availability_high estimate" scenario assumes that households that did not indicate using their garage for vehicle parking have zero garage spaces available. All other households are assumed 
to have their full garage capacity available for vehicular parking, even if the respondent reported using the garage for other purposes in addition to car parking.

The "actual availability-low estimate" scenario takes the high estimate scenario and tightens its assumptions. Like the high estimate scenario, the low estimate scenario assumes that households that reported not using their garage for vehicle parking have zero garage spaces available. Households that reported using their garage for vehicle parking only are similarly assumed to have their full garage capacity available for parking. But households that reported using their garage for both vehicle parking and another use were assigned just one available garage parking space (rather than the full nominal capacity, as in the high estimate scenario). This scenario therefore represents a lower bound on the likely availability of garage parking.

Figure 1 illustrates how the different scenarios play out across a range of stated garage uses for a hypothetical household that has a 2-car garage. The "Reality" column illustrates the unobserved reality behind the corresponding answer in the "Stated Garage Use in Survey" column. The columns on the right show how the stated use in the survey translates into our three scenarios. The hypothetical maximum supply and high estimate scenarios risk overestimating the actual parking space availability in reality, while the low estimate scenario risks underestimating it.

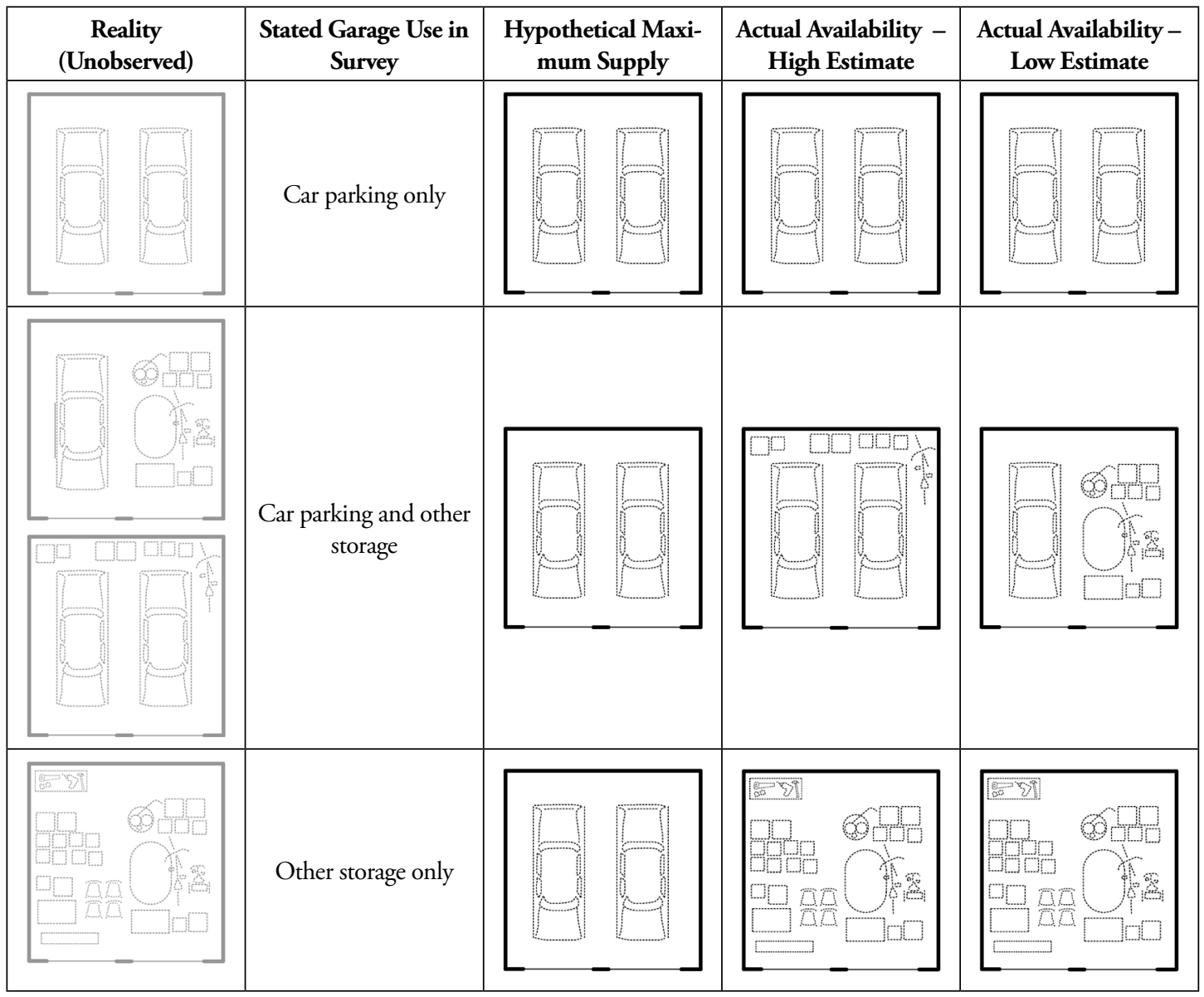

Figure 1. Three scenarios of garage parking space availability 


\subsection{Gauging on-street parking supply}

To estimate the full effective parking supply available to Sacramento's single-family homes, we also needed to ascertain the on-street parking supply in those areas. We did that by adapting the method from Guo et al. (2012) and Guo (2013), which is summarized above. Table 5 shows the numbers and data sources we used to estimate the average number of on-street parking spaces for single-family detached homes in Sacramento.

Table 5. Inputs for on-street parking supply estimate

\begin{tabular}{|c|c|c|}
\hline Input & Value & Source \\
\hline Lot size & 6,806 sq. ft. (0.16 acres) & Sacramento County (2020) \\
\hline Frontage-depth ratio & $1: 3$ & Various \\
\hline Parking space length & $22 \mathrm{ft}$. & $\begin{array}{r}\text { Sacramento City Planning and Development Code } \\
\text { section 17.608.040(F)(2)(a) }\end{array}$ \\
\hline Curb cut length & 25 ft. $(20$ ft. $* 1.25)$ & $\begin{array}{r}\text { Sacramento City Planning and Development Code } \\
\text { section 17.508.050; Thigpen \& Volker (2017) }\end{array}$ \\
\hline
\end{tabular}

We calculated the 6,806 square-foot average parcel size for single-family detached homes in the city from Sacramento County's Open Data portal (Sacramento County, 2020). We used all $(\mathrm{N}=112,368)$ parcels in the city that (1) were classified with a "most probable use" of Single Family-Subdivision, Single Family_Non-subdivision, or Single Family_Planned Unit Development, and (2) were between 2,000 square feet - the lowest minimum lot size in any residential zone in the city (City of Sacramento, n.d.) - and 1 acre (43,560 square feet) in size. We then estimated the average street line length for the parcels using a frontage-depth ratio of 1:3. Rather than use Guo et al.'s (2012) assumed average ratio of 2:3 for newer single-family lots (with houses built between 1970 and 2010) across the US, we decided to take a more context-sensitive approach. Our visual inspection of the parcel map maintained by the Sacramento County Assessor, our discussions with local planners, and our own observations in the city indicated that a 1:3 ratio was more representative of Sacramento lots. We also assume that only the front of each lot has street frontage and on-street parking spaces. While many lots in Sacramento also back onto alleys, "street" parking is usually not allowed in the alleys. Our method also discounts the street line length for corner lots. Each of these assumptions deliberately result in more conservative estimates.

To estimate the average number of on-street parking spaces per single-family detached home, we took the street line length, subtracted an assumed average curb cut length of 25 feet, and divided the remainder by a parking space length of 22 feet. We derived the 25 -foot curb cut length by conservatively assuming each home has the widest driveway (20 feet; City of Sacramento Planning and Development Code Section 17.508 .050 (n.d.) (A)) allowed by code for a 2-car parking area (the most common garage size in our weighted sample) and has another 5 feet $(25 \%)$ of unusable curb space adjacent to the driveway. The $25 \%$ fudge factor is the same value used by Thigpen and Volker (2017) based on observations of on-street parking conditions in residential neighborhoods in nearby Davis, California. The 22-foot parking space length is based on the city's minimum standards for (off-site) parallel parking spaces for standard vehicles (City of Sacramento, n.d., Planning and Development Code Section 17.608.040 (F) (2)(a)).

Overall, the assumptions undergirding our on-street parking calculus are intentionally conservative. We want to avoid overstating the effective parking supply (and any surplus) for single-family homes and the related capacity for ADU development. However, it bears noting that single-family households are not legally entitled to on-street parking on the public streets outside their homes. Their effective on-street parking supply could decrease if the city began charging for parking or otherwise restricted 
their access to on-street parking, e.g., by creating a parking meter zone (California Vehicle Code Section 22508 , n.d).

\subsection{Putting it all together-Total supply, surplus, and ADU implications}

We combined our off-street and on-street parking supply estimates to calculate the total effective parking supply (available spaces) and surplus (available spaces minus household vehicles) per house for Sacramento's single-family homes across the three off-street parking supply scenarios discussed above-hypothetical maximum supply, actual availability — high estimate, and actual availability—low estimate. This, in turn, allowed us to explore the effect on parking supply of adding an ADU to the average single-family detached home.

\subsection{Limitations}

Our findings are directly generalizable to the population of households that own single-family detached homes in Sacramento. Furthermore, they provide evidence of likely patterns of garage use and effective parking supply and demand in single-family neighborhoods in other urban areas with similar characteristics (like weather, lot size, garage prevalence, on-street parking regulations, household size, vehicle availability, the extent and quality of transit services, and other factors). There is good evidence that these types of residential neighborhoods are pervasive: research using a variety of data sources and methodologies has arrived at a consensus that the type of lower-density, suburban development patterns that characterize single-family neighborhoods are the most common land-use types in the US and globally (Barrington-Leigh \& Millard-Ball, 2015; Voulgaris et al., 2016; Wheeler, 2015). Furthermore, Census data confirms that Sacramento is broadly similar to California and the US with respect to patterns of household size and vehicle ownership for single-family detached homeowners. Of the 15 combinations of household size and vehicle ownership we use in this paper for weighting purposes, the most the city of Sacramento differs from California and the US is 3 and 5 percentage points, respectively, while the majority of categories differ by one percentage point or less. If researchers or city planners want to learn more about their particular city or region, they can also use this study's methodology in other settings. Given the dearth of studies on these topics, future research in other geographies would further our understanding of how garage use and single-family parking sufficiency might vary by context.

Future research is also needed to empirically quantify how parking demand from both ADUs and non-residents affects on-street parking occupancy. Our study assesses hypothetical effects only, using estimates of on-street parking supply from citywide data and estimates of occupancy rates and ADU-generated parking demand from previous studies. We could not calculate actual on-street parking supply or occupancy for the homes in our study - let alone discern where the parked cars come from-because our survey data does not include street-level geographic identifiers.

We use post-stratification weighting to bring a non-probability sample in line with the population of Sacramento single-family homeowners. This approach relies on the assumption that participants and non-participants within each "cell" (particular combination of household size and cars available) have the same distribution of the outcome variables (parking availability and use). If this assumption holds, it reduces selection biases. Many other studies of residential car parking, especially of garage use, rely on small or non-probabilistic samples, and few attempt to correct for misalignment of the sample with the population of interest. 


\section{$4 \quad$ Results}

\subsection{Garage use}

We first present our findings on garage capacity and use, since they are key to our estimates of effective parking supply and sufficiency. Our weighted estimates show that the vast majority of single-family detached households in Sacramento have garages (94.1\%), with an average nominal (built) capacity of 1.7 cars. Table 6 and Figure 2 show the overall frequency of individual garage uses among those households. The most common individual use is for storage, with over $75 \%$ of households using their garages for this purpose. This exceeds the $63 \%$ of households that use their garages at least partially for their intended purpose, car parking. Another somewhat common use was as an extra room (12\%), while the other use cases (as a living space used by the household or rented to a tenant) were much less common.

Table 6. Percent of garages used for different individual purposes

\begin{tabular}{lll}
\hline Garage use & Estimate & S.E. \\
\hline Storage & $75.5 \%$ & 2.60 \\
\hline Car Parking and Repair & $63.0 \%$ & 2.92 \\
\hline Extra Room & $12.1 \%$ & 1.99 \\
\hline Household Living Space & $3.1 \%$ & 1.20 \\
\hline Rented Living Space & $1.7 \%$ & 1.00 \\
\hline
\end{tabular}

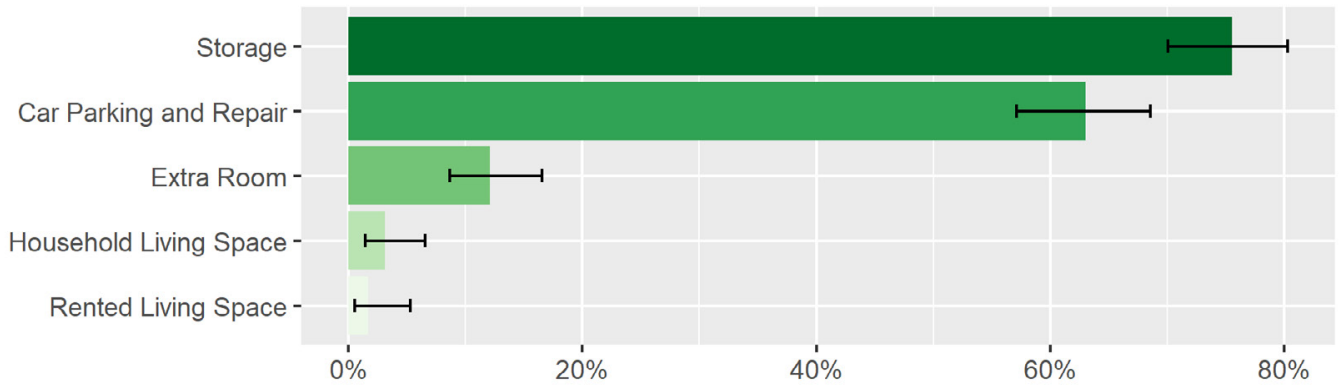

Figure 2. Percent of garages used for different individual purposes

Note: Error bars depict the $95 \%$ confidence intervals

Table 7 and Figure 3 show the prevalence of different combinations of simultaneous garage uses amongst single-family households with garages. We find that the most common use combination is for both car parking and storage (40\%). Interestingly, more respondents indicated using their garage for storage only $(27 \%)$ than for car parking only $(18 \%)$. The next most common uses were as an extra room (not as a living space) only (5\%) and as an extra room and storage (4\%). The remaining combinations all had low frequencies. We examined the association of garage use with various household characteristics and found no strong associations. 
Table 7. Percent of garages used for different combined purposes

\begin{tabular}{rrr}
\hline Garage use combinations & Estimate & S.E. \\
\hline Car Parking and Storage & $39.9 \%$ & 3.04 \\
\hline Storage only & $26.6 \%$ & 2.71 \\
\hline Car Parking only & $18.4 \%$ & 2.16 \\
\hline Extra Room only & $4.7 \%$ & 1.54 \\
\hline Storage and Extra Room & $3.5 \%$ & 0.89 \\
\hline Combinations with only 1 response & $3.0 \%$ & 1.17 \\
\hline Car Parking, Storage, and Extra Room & $2.7 \%$ & 0.97 \\
\hline Car Parking, Storage, and Household & $0.7 \%$ & 0.43 \\
\hline Living Space & & 0.31 \\
\hline
\end{tabular}

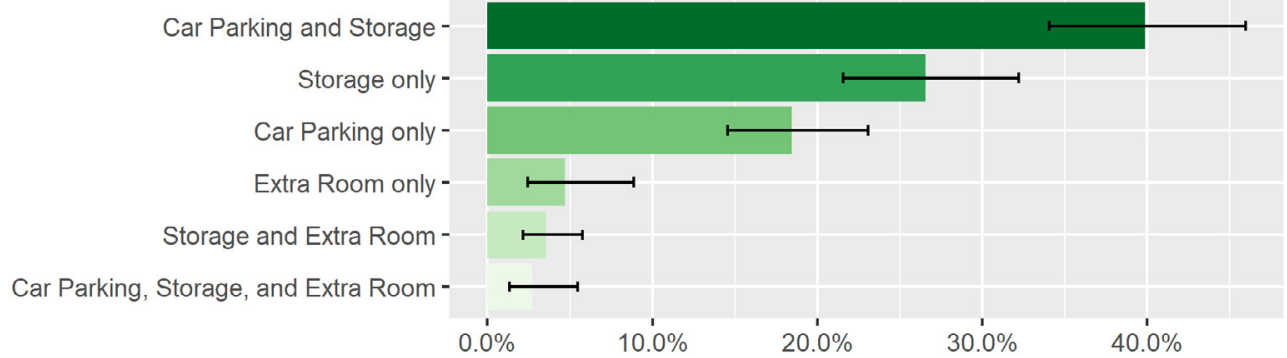

Figure 3. Percent of garages used for different combined purposes Note: Error bars depict $95 \%$ confidence intervals

\subsection{Off-street parking supply and sufficiency}

Looking at the total supply and sufficiency of off-street parking supply_-garage spaces plus other offstreet spaces - we find that most single-family detached households in Sacramento have sufficient offstreet capacity to park all their vehicles. On average, households had 2.3 vehicles and between 2.9 and 3.8 total off-street spaces, depending on the scenario. Overall, parking supply sufficiency ranged from a surplus of $6+$ off-street spaces to a shortage of 3 spaces. Table 8 and Figure 4 show our population-level estimates for the percent of households across the 10-level range of parking sufficiency for each of our three scenarios. These estimates are based on our full sample, including households without garages.

In the hypothetical "maximum supply" scenario with all garage spaces available for car parking, only $8 \%$ of households would need to park a car(s) on the street. The remaining $92 \%$ of households would have sufficient off-street parking supply to store their car(s). About one in five (20\%) households have as many cars as theoretically-available off-street spaces, and the majority (64\%) have 1 to 3 extra off-street spaces remaining.

In the more realistic scenario with an upper-end estimate for available garage spaces (actual availability-high estimate), the percent of households that have more cars than off-street spaces nearly doubles from $8 \%$ in the hypothetical scenario to $15 \%$. The percentage of households with as many cars as off-street spaces also increases from $20 \%$ to over a quarter of households (29\%). But a majority (50\%) still have 1 to 3 extra off-street spaces remaining.

In the more realistic scenario with a lower-end estimate for available garage spaces (actual availabil- 
ity-low estimate), approximately one in four households (25\%) have more cars than off-street parking spaces, which is similar to Taylor's (2020) estimate from Melbourne (26\%). The percent of households with equal numbers of cars as off-street spaces remains at $29 \%$, and the percent of households with 1 to 3 remaining off-street spaces declines to $42 \%$.

Table 8. Percent of households with off-street parking spaces remaining

\begin{tabular}{lllllll}
\hline & \multicolumn{2}{l}{$\begin{array}{l}\text { Hypothetical } \\
\text { Maximum Supply }\end{array}$} & \multicolumn{2}{l}{$\begin{array}{l}\text { Actual Availability - } \\
\text { High Estimate }\end{array}$} & \multicolumn{2}{l}{$\begin{array}{l}\text { Actual Availability - } \\
\text { Low Estimate }\end{array}$} \\
\hline Off-street spaces remaining & Estimate & S.E. & Estimate & S.E. & Estimate & S.E. \\
\hline 6 or more off-street spaces remaining & $1.0 \%$ & 0.5 & $1.0 \%$ & 0.5 & $1.0 \%$ & 0.5 \\
\hline 5 off-street spaces remaining & $1.9 \%$ & 0.9 & $1.2 \%$ & 0.5 & $0.7 \%$ & 0.4 \\
\hline 4 off-street spaces remaining & $5.1 \%$ & 1.2 & $3.5 \%$ & 0.8 & $2.3 \%$ & 0.8 \\
\hline 3 off-street spaces remaining & $14.9 \%$ & 2.0 & $10.7 \%$ & 1.9 & $3.9 \%$ & 1.1 \\
\hline 2 off-street spaces remaining & $27.4 \%$ & 2.5 & $18.4 \%$ & 2.1 & $15.5 \%$ & 2.0 \\
\hline 1 off-street spaces remaining & $21.6 \%$ & 2.5 & $20.8 \%$ & 2.4 & $22.7 \%$ & 2.3 \\
\hline Off-street capacity full & $20.0 \%$ & 2.6 & $29.3 \%$ & 2.9 & $29.1 \%$ & 2.9 \\
\hline Exceeds off-street capacity by 1 & $5.0 \%$ & 1.6 & $9.5 \%$ & 2.1 & $18.0 \%$ & 2.6 \\
\hline Exceeds off-street capacity by 2 & $0.8 \%$ & 0.3 & $3.4 \%$ & 1.2 & $4.5 \%$ & 1.5 \\
\hline Exceeds off-street capacity by 3 & $2.1 \%$ & 1.2 & $2.2 \%$ & 1.2 & $2.2 \%$ & 1.2 \\
\hline
\end{tabular}

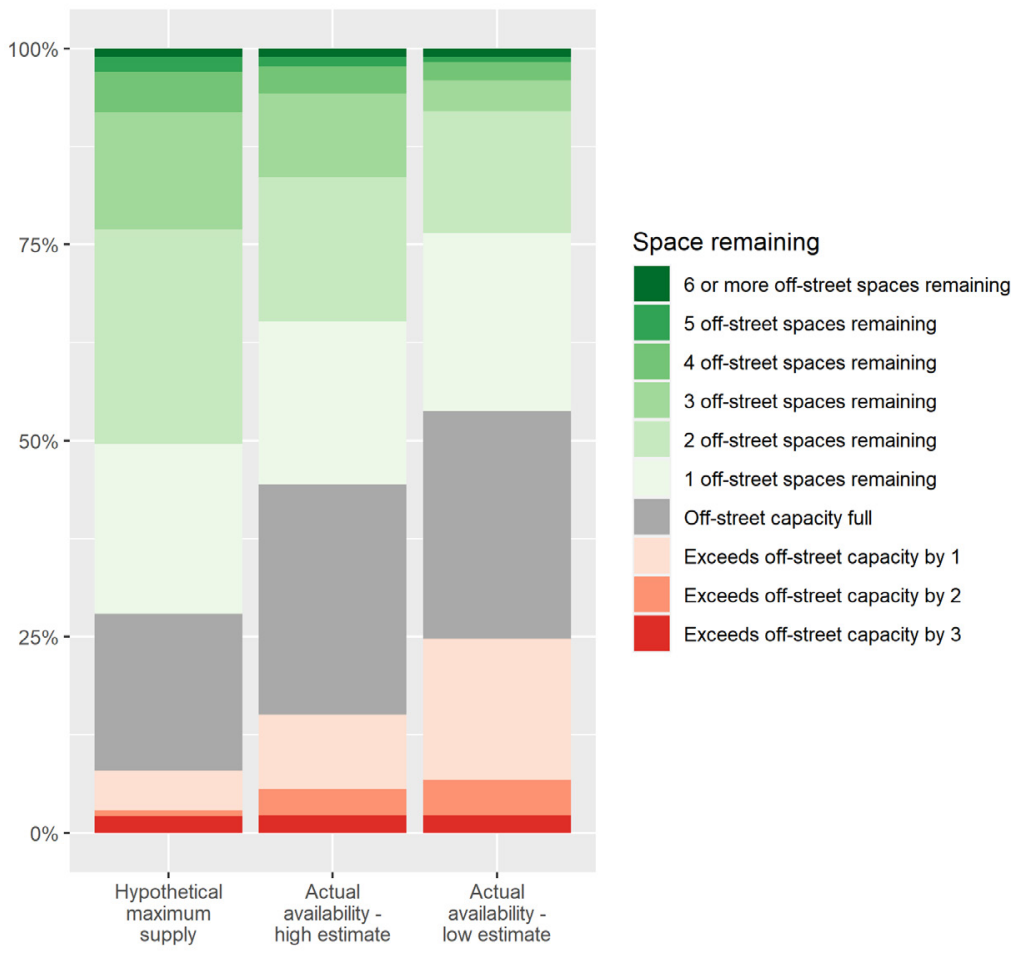

Figure 4. Percent of households with off-street parking spaces remaining 


\subsection{On-street parking supply}

Using the inputs listed in Table 5, we estimated that the average single-family detached home in Sacramento has approximately 48 feet of street frontage. We then subtracted 25 feet to account for a driveway curb cut ( 20 feet) and potentially unusable curb space ( 5 feet), yielding 23 feet of curb space. That translates to almost exactly one on-street parking space per average single-family detached home, using a parking space length of 22 feet.

\subsection{Total effective parking supply and sufficiency}

Table 9 shows the average total effective parking supply (available off-street and on-street spaces combined) and surplus (available spaces minus available household vehicles) per single-family home across the three off-street parking supply scenarios. The average single-family detached household in Sacramento has access to between 1.6 and 2.0 more parking spaces than it has vehicles, according to our low and high estimates of actual (realistic) parking space availability, respectively. The average surplus increases to 2.5 spaces under the hypothetical maximum.

Achieving the hypothetical maximum might not be feasible, since it would require every household to clear enough space in their garage to accommodate its nominal vehicular capacity-i.e., each 1-car garage could actually fit 1 car, each 2 -car garage could actually fit 2 cars, etc. That would mean displacing storage, home gyms, home offices, and even dwelling areas in some cases, which many homeowners likely have no self-interest in doing. In any case, our results indicate that Sacramento's single-family detached homes have a substantial surplus of parking spaces under any of the three scenarios.

Table 9. Total effective parking supply and surplus per home

\begin{tabular}{llllll}
\hline Scenario & $\begin{array}{l}\text { Average on- } \\
\text { street spaces }\end{array}$ & $\begin{array}{l}\text { Average off- } \\
\text { street spaces }\end{array}$ & $\begin{array}{l}\text { Average total } \\
\text { spaces }\end{array}$ & $\begin{array}{l}\text { Average ve- } \\
\text { hicles available }\end{array}$ & $\begin{array}{l}\text { Average surplus } \\
\text { spaces }\end{array}$ \\
\hline & $\mathrm{A}$ & $\mathrm{B}$ & $\mathrm{A}+\mathrm{B}=\mathrm{C}$ & $\mathrm{D}$ & $\mathrm{C}-\mathrm{D}=\mathrm{E}$ \\
\hline $\begin{array}{l}\text { Hypothetical maximum } \\
\text { supply }\end{array}$ & 1.1 & $3.8(0.09)$ & $4.9(0.09)$ & $2.3(0.05)$ & $2.5(0.10)$ \\
\hline $\begin{array}{l}\text { Actual availability - high } \\
\text { estimate }\end{array}$ & 1.1 & $3.3(0.10)$ & $4.3(0.10)$ & $2.3(0.05)$ & $2.0(0.10)$ \\
\hline $\begin{array}{l}\text { Actual availability - low } \\
\text { estimate }\end{array}$ & 1.1 & $2.9(0.09)$ & $3.9(0.09)$ & $2.3(0.05)$ & $1.6(0.09)$ \\
\hline
\end{tabular}

Note: Sums may be off by one tenth due to rounding.

\section{Discussion}

\subsection{Garage use}

Our study expands the small, yet slowly growing, body of research on off-street parking use by revealing the multifaceted ways that Sacramento homeowners use their garage space: primarily for storage, secondarily for car parking, and marginally for other purposes, like living spaces. Our research improves on earlier work by explicitly allowing respondents to select multiple simultaneous garage use categories, reflecting the multi-dimensional use cases seen in many homes (Taylor (2020) being a notable exception to this pattern). However, this makes direct comparisons with previous findings more difficult, as does the fact that the study setting is novel. Nonetheless, it is useful to assess the consistency of findings as we seek to build the evidence base on garage uses. 
Our results align well with the general pattern of previous findings that the two main garage uses are storing personal belongings and parking cars. An overwhelming majority of Sacramento singlefamily homeowners $(76 \%)$ use their garage for storage, in rough agreement with the qualitative results of the Guo et al. (2012) expert opinion survey. By contrast, our estimate of the percent of Sacramento single-family households using their garage for car parking (63\%) was generally higher than studies in cities such as San Francisco (51\%) (Brown, 2007), Melbourne (41\%) (Taylor, 2020), UK cities (3645\%) (United Kingdom Department for Transport, 2007), and especially New York City (13\%) (Guo, 2013). Only one previous study had a similarly high estimate (62\%) to ours, and that was in a suburb of Reading, England (Jenks \& Noble, 1996, as discussed in Guo \& Schloeter, 2013, 460). This pattern of results from the literature suggests that residents of cities with older and smaller housing stock may be enticed to convert their garages to other purposes and park their car elsewhere.

Our estimate of the percentage of households using their garage as a living space, either for the household or rented to others (3.7\%), roughly matches the findings in Chavez and Quinn's systematic field observations (3.2\%; Chavez \& Quinn, 1987), while falling much lower than the more informal estimates of Wegmann (2015) and of the City of Compton city planner (Garrison, 2009). Though the disparities could be attributable to differences in the study setting, it is also notable that the two studies using formal quantitative methods and statistical sampling techniques yielded similar results.

\subsection{Surplus parking spaces available to single-family homes}

Our study provides the first estimate we have seen of the total effective parking supply and use for singlefamily detached homes. Our findings indicate that Sacramento's single-family homes have a sizeable surplus of parking. We estimate that the average single-family detached homeowner in Sacramento has access to between 1.6 and 2.0 more parking spaces than their household has vehicles, using our low and high estimates of actual parking availability, respectively (Table 9). Our findings are consistent with other indications that parking tends to be oversupplied in single-family neighborhoods, including studies showing low occupancy rates for on-street parking (Roth, 2016; Schlossberg \& Amos, 2015; Thigpen \& Volker, 2017) and the sufficiency of off-street parking for most households (Taylor, 2020).

The surplus could be even greater in areas with larger average lot sizes. For example, Guo et al. (2012) estimated that new single-family homes built in the US between 1970 and 2010 had a hypothetical maximum of 8-10 total parking spaces on an average lot size of 0.34 acres. Both numbers are more than double their respective values in Sacramento, where we estimated a hypothetical maximum of 4.9 parking spaces and an average lot size of 0.16 acres. However, Guo et al. (2012) did not estimate parking surplus.

Another way to conceptualize the surplus is as the ratio of total parking spaces to vehicles available to single-family detached homeowners. This compares to the more widely reported ratio of all parking spaces (residential, commercial, and otherwise) to all passenger vehicles. The oft-cited "rule of thumb" estimate for the US is 8 parking spaces per vehicle, but survey-based estimates have been considerably lower. (Chester et al., 2010), for example, calculate a ratio of 3.4 to 1 , combining separate survey-based estimates for urban areas and rural areas. For single-family detached homes in Sacramento, we estimate that there are between 1.5 and 1.9 residential parking spaces per vehicle on average, using our low and high estimates of actual parking availability respectively.

\subsection{Implications for ADUs}

Under any of our three scenarios, the parking surplus for the average single-family detached home in Sacramento is more than enough to accommodate the average ADU tenant. Households living in 
ADUs have an average of just one vehicle available to them, according to studies in Portland (Brown \& Palmeri, 2014; Gebhardt et al., 2018) and the San Francisco Bay Area (Chapple et al., 2012; City of Sausalito, 2011; Wegmann \& Chapple, 2012). Allocating one parking space for the ADU tenants would still leave the average single-family home with 0.6 to 1.0 surplus parking spaces at periods of maximum residential utilization (when all the vehicles available to the primary home and the ADU were parked at home at the same time), using our low and high estimates of actual parking availability.

Scaling our findings up to the block level, a hypothetical 500-foot block face with 10 single-family houses and no ADUs would have about 16 to 20 (rounded) surplus parking spaces not used by the households that live there. Figure 5, panel A shows a conservative version of this scenario, where we allocate to each house 3 off-street parking spaces (in between our low and high estimates in Table 9, but closer to the low estimate), 1 on-street space (rounded down from our estimate in Table 9) and 2 or 3 vehicles (totaling 23 vehicles across the block to match the weighted average of 2.3 vehicles per household from our sample). For simplicity, we assume that all household vehicles are parked on the block during a period of maximum residential utilization (like the middle of the night), that households will park their vehicles off the street as long as spaces remain available, and that there are no non-resident vehicles parked on the block. Occupied parking spaces are shown as red-filled rectangles and vacant spaces are shown as dashed white rectangles. For ease of visualization, all off-street parking spaces are shown in front of the garage. In reality, our results show that about 1 vehicle would be parked in the garage for the average single-family detached home in Sacramento. In total, there are 23 occupied offstreet spaces, 7 vacant off-street spaces, and 10 vacant on-street spaces under this scenario, for a total of 17 surplus spaces.

A

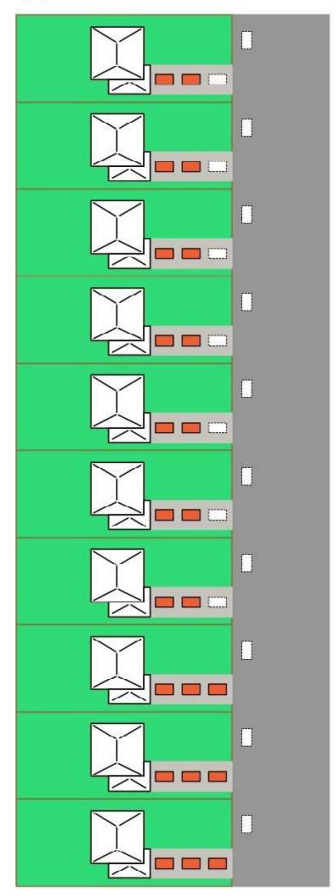

B

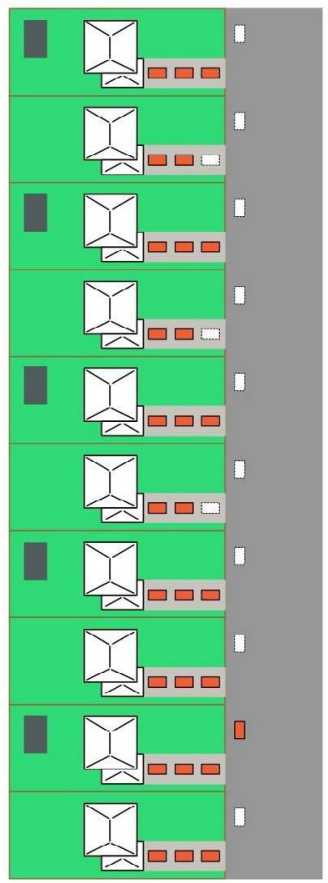

C

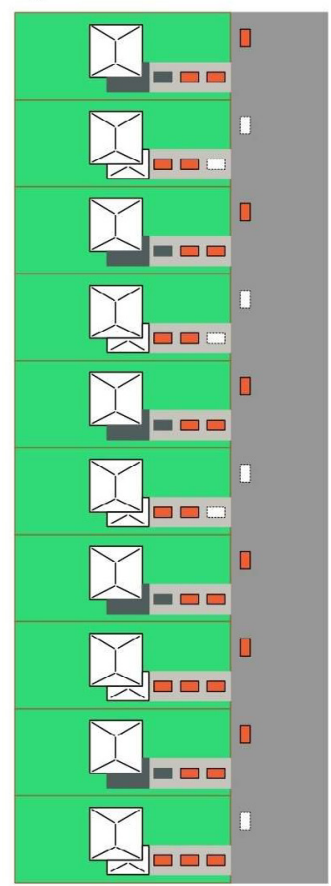

Figure 5. Block-level parking occupancy scenarios

How much does the surplus change if we add in ADUs? A recent study estimated that nearly $50 \%$ of single-family detached homeowners in Sacramento could be open to building an ADU (Volker \& Handy, in press). Using 50\% as a maximum ADU adoption scenario, we will assume that five of the 10 households on our hypothetical block have ADUs, with each ADU generating one vehicle (in line with 
the average from the literature). Figure 5, panel B illustrates this scenario. We use the same assumptions as the scenario in panel A with one difference-we allocate one additional vehicle to every other house on the block (for a total of 28 resident vehicles on the block). The houses with the additional vehicle are indicated by the ADU (gray rectangle) in the backyard. In total, there are 26 occupied off-street spaces, 1 occupied on-street space, 3 vacant off-street spaces, and 9 vacant on-street spaces under this scenario, for a total of 12 surplus spaces.

But what if the ADUs also reduced neighborhood parking supply? Let us assume for the sake of argument that every $\mathrm{ADU}$ in the previous scenario was converted from a garage. Our weighted estimates show that the average single-family homeowner in Sacramento stores between 0.7 and 1.1 vehicles in their garage, based on our low- and high-availability scenarios respectively. Using the higher estimate, each ADU would remove 1.1 parking spaces in addition to adding one vehicle to the total neighborhood parking demand. Figure 5, panel C illustrates this scenario, though for simplicity it uses a round number of 1 vehicle per garage rather than our 1.1-vehicle high estimate. We use the same assumptions as the scenario in panel B except we remove one off-street parking space from each house with an ADU (depicted as a gray ADU rectangle where the garage and accompanying off-street parking space used to be). In total, there are 22 occupied off-street spaces, 6 occupied on-street spaces, 3 vacant off-street spaces, and 4 vacant on-street spaces, for a total of 7 surplus spaces.

Under all three hypothetical scenarios shown in Figure 5 there would be numerous vacant on-street spaces on the 10-house block during periods of maximum residential occupancy. Of course, this does not mean that there would always be empty on-street parking spaces on the block. Even where the total number of parking spaces (off-street and on-street) exceeds the number of vehicles available to residents on the block, the cumulative parking demand from the residents plus visitors, home help, and other non-residents could exceed the total supply. This could be especially problematic on blocks with retail or commercial uses or within walking distance of concentrated retail, commercial, or recreational activities.

However, previous censuses of on-street parking in single-family neighborhoods indicate that onstreet parking is vastly oversupplied even during times of peak occupancy, suggesting our conservative assumptions might result in an overestimate of on-street parking impacts. Thigpen and Volker (2017), Schlossberg and Amos (2015), and Roth (2016) all found vacancy rates between 71\% and 89\%. Furthermore, local governments have numerous tools available to help ensure that residents of high-use areas have enough parking without requiring that homeowners add off-street parking for their ADUs or replace off-street parking that was converted into an ADU (Brown et al., 2017). They can create a residential parking permit district to restrict longer-term on-street parking to permitted residents, like Sacramento and most other large cities in the United States have already done in many places (City of Sacramento, 2021c). They can also allow residents to park in front of their own driveways. The California Vehicle Code, for example, allows local governments to "authorize the owner or lessee of property to park a vehicle in front of the owner's or lessee's private driveway when the vehicle displays a permit issued pursuant to the ordinance authorizing such parking" (California Vehicle Code Section 22507.2, n.d.). In the case of Sacramento, the additional space provided by blocking the driveway would double the number of on-street spaces available to the average single-family home (according to our estimate of 1.05 spaces), and would effectively replace any on-street parking used by non-residents.

Overall, our findings tend to belie claims that ADUs will overwhelm existing parking supplies in single-family neighborhoods. They also cast doubt on the necessity of off-street parking requirements for ADUs. 


\section{Conclusion}

In this article, we use a survey of homeowners in Sacramento, California to investigate the supply and sufficiency of residential parking supply in single-family neighborhoods, including how households actually use their garages. We use our findings on these sorely understudied topics to examine one of the most commonly cited reasons for opposing construction of accessory dwelling units in single-family neighborhoods - that the new residents would overwhelm scarce on-street parking. We find that $63 \%$ of single-family detached homeowners in Sacramento use their garage at least partially for car parking. However, only $18 \%$ use their garage solely to park cars. On the other hand, $27 \%$ of households use their garage exclusively for storage. With respect to parking sufficiency, we find that, even under our most conservative scenario, $75 \%$ of households have enough off-street parking to park all their vehicles. Combining off-street and on-street parking supplies, we find-again under our most conservative scenario- that Sacramento's single-family detached households have, on average, 1.6 more parking spaces available to them than they have vehicles. That surplus is more than enough to accommodate the average ADU tenant and their vehicle. That belies claims that ADUs will overwhelm existing parking supplies in single-family neighborhoods.

\section{Acknowledgments}

The authors thank the National Center for Sustainable Transportation for providing crucial funding for this research through a Dissertation Fellowship to Dr. Volker. Thank you also to the editors and the reviewers for their constructive feedback, which improved the paper's focus and quality. 


\section{References}

Anacker, K. B., \& Niedt, C. (2019). Classifying regulatory approaches of jurisdictions for accessory dwelling units: The case of Long Island. Journal of Planning Education and Research. https://doi. org/10.1177/0739456X19856068

Anirudh, B., Mazumder, T. N., \& Das, A. (2021). A contemporary review of residential parking lessons for Indian cities. Housing Policy Debate. https://doi.org/10.1080/10511482.2021.1909630

Arnold, J., Graesch, A., Ragazzini, E., \& Ochs, E. (2012). Life at home in the twenty-first century: 32 families open their doors. Los Angeles: Cotsen Institute of Archaeology Press.

Arnold, J. E., \& Lang, U. A. (2007). Changing American home life: Trends in domestic leisure and storage among middle-class families. Journal of Family and Economic Issues, 28, 23-48. https://doi. org/10.1007/s10834-006-9052-5

Barrington-Leigh, C., \& Millard-Ball, A. (2015). A century of sprawl in the United States. Proceedings of the National Academy of Sciences, 27, 8244-8249. https://doi.org/10.1073/pnas.1504033112

Brown, A., Mukhija, V., \& Shoup, D. (2017). Converting garages into housing. Journal of Planning Education and Research 40, 56-68. https://doi.org/10.1177/0739456X17741965

Brown, M. (2007). Shifting landscapes of mobility: Reconfiguring space in the mission district for automobiles (master's thesis), San Francisco State University. Retrieved from https://marybrown.files.wordpress.com/2008/01/introduction_toc.pdf

Brown, M. J., \& Palmeri, J. (2014). Accessory dwelling units in Portland, Oregon:

Evaluation and interpretation of a survey of $A D U$ owners. Salem, OR: Department of Environmental Quality. Retrieved from https://accessorydwellings.files.wordpress.com/2014/06/adusurveyinterpret.pdf

California Assembly Bill 881. (2019-2020). Chapter 659 (Cal. Stat. 2019). Retrieved from

https://leginfo.legislature.ca.gov/faces/billTextClient.xhtml?bill_id=201920200AB881

California Department of Finance. (2019). E-1 population estimates for cities, counties and the state with annual percent change - January 1, 2018 and 2019. Sacramento, CA: California Department of Finance.

California Government Code. (n.d.). Title 7, Division 1, Section 65852.2. Retrieved from https://codes. findlaw.com/ca/government-code/gov-sect-65852-2.html

California Vehicle Code. (n.d.). Division 11, Section 22507.2. Retrieved from https://leginfo.legislature. ca.gov/faces/codes_displaySection.xhtml?lawCode=VEH\&sectionNum $=22507.2$

California Vehicle Code. (n.d.) Division 11, Section 22508. Retrieved from https://leginfo.legislature. ca.gov/faces/codes_displaySection.xhtml?lawCode=VEH\&sectionNum=22508.

Casey, D. (2020). COVID-19 stopped the economy, but our housing shortage remains. CaRLA continues to fight for the answer to both: $A D U$ s. Retrieved from https://carlaef.org/2020/04/16/covid-19-stoppedthe-economy-but-our-housing-shortage-remains-carla-continues-to-fight-for-the-answer-to-bothadus/

Chapple, K., Lieberworth, A., Ganetsos, D., Valchuis, E., Kwang, A., \& Schten, R. (2020). ADUs in California: A revolution in progress. Berkeley, CA: UC Berkeley Center for Community Innovation. Retrieved from https:/www.aducalifornia.org/wp-content/uploads/2020/10/ADU-Progress-inCalifornia-Report-October-Version.pdf

Chapple, K., Wegmann, J., Mashhood, F., \& Coleman, R. (2017). Jumpstarting the market for accessory dwelling units: Lessons learned from Portland, Seattle and Vancouver. Berkeley, CA: UC Berkeley Terner Center for Housing Innovation, UC Berkeley Center for Community Innovation, and the Urban Land Institute. Retrieved from https:/ternercenter.berkeley.edu/wp-content/uploads/pdfs/ Jumpstarting_the_Market_--_ULI.pdf 
Chapple, K., Wegmann, J., Nemirow, A., \& Dentel-Post, C. (2012). Yes in my backyard: Mobilizing the market for secondary units. Berkeley, CA: UC Berkeley Center for Community Innovation. Retrieved from https://communityinnovation.berkeley.edu/sites/default/files/yes_in_my_backyard_mobilizing_the_market_for_secondary_units.pdf?width $=1200$ \&height $=800$ \&iframe $=$ true

Chavez, S., \& Quinn, J. (1987). Substandard housing: Garages: Immigrants in, cars out. Los Angeles Times. Retrieved from https://www.latimes.com/archives/la-xpm-1987-05-24-mn-2558-story.html

Chester, M., Horvath, A., \& Madanat, S. (2010). Parking infrastructure: Energy, emissions, and automobile life-cycle environmental accounting. Environmental Research Letters, 5, 034001. https://doi. org/10.1088/1748-9326/5/3/034001

Cho, J. (2016). Second units in the Silicon Valley. The Urban Lawyer, 48, 459-488.

Retrieved from https://www.jstor.org/stable/44648239?refreqid=excelsior\%3Ac5adb6bbd311283df81 $4 \mathrm{e} 142087899 \mathrm{df}$

City of Sacramento. (2021a). Accessory dwelling units. Retrieved from https://www.cityofsacramento. org/Community-Development/Resources/Accessory-Dwelling-Units

City of Sacramento. (2021b). 2021-2029 housing element. Retrieved from https://www.cityofsacramento.org/-/media/Corporate/Files/CDD/Planning/Long-Range/Housing-Element/00_Sac-HE_ Amended_Final_Dec142021.pdf?la=en

City of Sacramento. (2021c). Residential parking permit program. Retrieved from http://www.cityofsacramento.org/public-works/parking-services/street-parking/parking-permits/Residential

City of Sacramento. (n.d.). Planning and development code map book. Retrieved from https://www. cityofsacramento.org/-/media/Corporate/Files/CDD/Planning/Maps/ZoningDefinitions.pdf?la=en

City of Sacramento. (n.d.). Planning and development code. Section 17.508.050. Retrieved from https:// www.qcode.us/codes/sacramento/view.php?topic=17-v-17_508-17_508_050

City of Sacramento. (n.d.). Planning and development code. Section 17.608.040(F)(2)(a). Retrieved from https://www.qcode.us/codes/sacramento/view.php?topic=17-vi-17_608-17_608_040

City of Sausalito. (2011). Accessory dwelling unit survey technical report: Two-family and multifamily zoning districts. Retrieved from https://www.sausalito.gov/home/showpublisheddocument/9557/636326254065130000

Garrison, J. (2009). Compton cracking down on illegal garage conversions. Los Angeles Times. Retrieved from https:/www.latimes.com/archives/la-xpm-2009-may-06-me-compton-garages6-story.html

Gebhardt, M., Gilden, B., \& Kidron, Y. (2018). Accessory dwelling units in Portland,

Oregon ISS survey 1st report. (Report No. 118). Portland, OR: Institute for Sustainable Solutions Publications and Presentations, Portland State University. Retrieved from https://pdxscholar.library.pdx. edu/cgi/viewcontent.cgi?article=1119\&context=iss_pub

Guo, Z. (2013). Residential street parking and car ownership. Journal of the American Planning Association 79, 32-48. https://doi.org/10.1080/01944363.2013.790100

Guo, Z., Rivasplata, C., Lee, R., Keyon, D., \& Schloeter, L. (2012). Amenity or necessity? Street standards as parking policy (MTI Report 11-23). San Jose, CA: Mineta Transportation Institute, San Jose State University. Retrieved from https://transweb.sjsu.edu/sites/default/files/1001-2-street-standards-street-width-parking-policy-investigation.pdf

Guo, Z., \& Schloeter, L. (2013). Street standards as parking policy: Rethinking the provision of residential street parking in American suburbs. Journal of Planning Education and Research, 33, 456-470. https://doi.org/10.1177/0739456X13504299

Jenks, M., and Noble, J. (1996). Parking: Demand and provision in private sector housing development. Oxford, UK: Oxford Brookes University.

Kalton, G., \& Flores-Cervantes, I. (2003). Weighting methods. Journal of Official Statistics, 19, 81-97. 
Morales, R. (2019). Evaluating accessory dwelling unit (ADU) friendliness: The case of the San Gabriel Valley [Master's thesis]. California State Polytechnic University, Pomona, CA. Retrieved from https:// scholarworks.calstate.edu/concern/theses/kk91fn80x?locale=en

Pfeiffer, D. (2019). Regulating ADUs in California: Local approaches \& outcomes. Berkeley, CA: UC Berkeley Terner Center for Housing Innovation. Retrieved from https:/californialanduse.org/ download/Pfeiffer_Regulating_ADUs_in_California.pdf

RAC Media Center. (2021). Nearly six million UK garages not used for cars as they're too full of junk. Retrieved from https://media.rac.co.uk/pressreleases/nearly-six-million-uk-garages-not-used-for-carsas-theyre-too-full-of-junk-3112460

Roth, D. (2016). A review of the residential parking management program in Bellevue, WA [Master's thesis]. University of Washington, Seattle. Retrieved from https://digital.lib.washington.edu/researchworks/bitstream/handle/1773/36857/Roth_washington_0250O_15900.pdf?sequence=1

Sacramento County. (2020). Sacramento County open data: Parcels. Retrieved from https://data.saccounty.gov/datasets/sacramentocounty:parcels/about

Scheiner, J., Faust, N., Helmer, J., Straub, M., \& Holz-Rau, C. (2020). What's that garage for? Private parking and on-street parking in a high-density urban residential neighborhood. Journal of Transport Geography, 85, 102714. https://doi.org/10.1016/j.jtrangeo.2020.102714

Schlossberg, M., \& Amos, D. (2015). Rethinking residential on-street parking. In E. Talen (Ed.), Retrofitting sprawl: Addressing 70 years of failed urban form (pp. 181-198). Athens, GA: University of Georgia Press.

Taylor, E. J. (2020). Parking policy: The politics and uneven use of residential parking space in Melbourne. Land Use Policy, 91, 103706. https://doi.org/10.1016/j.landusepol.2018.11.011

Thigpen, C., \& Volker, J. (2017). Repurposing the paving: The case of surplus residential parking in Davis, CA. Cities, 70, 111-121. https://doi.org/10.1016/j.cities.2017.06.020

United Kingdom Department for Transport. (2007). Manual for streets. London: Thomas Telford Publishing.

US Census Bureau. (2018a). 1-year American community survey estimates. Washington, DC: US Census Bureau.

US Census Bureau. (2018b). 5-year American community survey estimates. Washington, DC: US Census Bureau.

US Census Bureau. (2017). 1-year American community survey estimates. Washington, DC: US Census Bureau.

US Census Bureau. (2010). Decennial census. Washington, DC: US Census Bureau.

US Census Bureau. (2003a). Census 2000, public use microdata sample (PUMS), United States. Washington, DC: US Census Bureau.

US Census Bureau. (2003b). Census 2000, public use microdata sample, (PUMS), United States [Technical documentation]. Washington, DC: US Census Bureau.

Volker, J. (2020). Exploring the changing faces of housing development and demand in California: Millennials, casitas, and reducing VMT [doctoral dissertation]. University of California, Davis. Retrieved from https://www.proquest.com/openview/86f78eeb9e9ae237d7a34bb90e5c45a4/1?pq-origsite=g scholar\&cbl=51922\&diss $=\mathrm{y}$

Volker, J. M. B., \& Handy, S. (in press). Exploring homeowners' openness to building accessory dwelling units in the Sacramento Metropolitan Area. Journal of the American Planning Association. https://doi.org/10.1080/01944363.2022.2036222

Volker, J. M. B., Lee, A. E., \& Fitch, D. T. (2019). Streamlining the development approval process in a post-level of service Los Angeles. Journal of the American Planning Association, 85, 114-132. https:// doi.org/10.1080/01944363.2019.1601587 
Voulgaris, C. T., Taylor, B. D., Blumenberg, E., Brown, A., \& Ralph, K. (2016). Synergistic neighborhood relationships with travel behavior: An analysis of travel in 30,000 US neighborhoods. Journal of Transportation and Land Use, 10, 437-461. https://doi.org/10.5198/jtlu.2016.840

Wegmann, J. (2015). Research notes: The hidden cityscapes of informal housing in suburban Los Angeles and the paradox of horizontal density. Buildings \& Landscapes, 22, 89-111.

Wegmann, J., \& Chapple, K. (2012). Understanding the market for secondary units in the East Bay. (No. 2012-03). Berkeley, CA: UC Berkeley Institute of Urban and Regional Development. Retrieved from https://escholarship.org/uc/item/9932417c

Wheeler, S. M. (2015). Built landscapes of metropolitan regions: An international typology. Journal of the American Planning Association, 81, 167-190. https://doi.org/10.1080/01944363.2015.1081567

Willson, R. (2000). Reading between the regulations: Parking requirements, planners' perspectives, and transit. Journal of Public Transportation, 3, 111-128. https://doi.org/10.5038/2375-0901.3.1.6

Woetzel, J., Mischke, J., Peloquin, S., \& Weisfield, D. (2016). A tool kit to close California's housing gap: 3.5 million homes by 2025. New York: McKinsey Global Institute. Retrieved from https://www. mckinsey.com/ /media/mckinsey/industries/public\%20and\%20social\%20sector/our\%20insights/ closing\%20californias\%20housing\%20gap/closing-californias-housing-gap-full-report.pdf 